\title{
RĪGAS POLITEHNISKĀ INSTITŪTA ABSOLVENTS, INŽENIERIS, IZGUDROTĀJS UN SPORTISTS ARNO LİCIS
}

\section{ËRIKA LANKA*}

Latvijas Universitāte

ALİDA ZIGMUNDE

Rīgas Tehniskā universitāte

\begin{abstract}
Kopsavilkums. Rakstā apkopots Rīgas Politehniskā institūta (RPI) Mehānikas fakultātes 1964. gada absolventa Arno Līča veikums inženiera profesijā Rīgas elektromašīnbūves rūpnīcā (RER), Latvijas Traumatologijas un ortopēdijas zinātniskās pētniecības institūtā (LTOZPI) un tipogrāfijā «Jāṇa sēta», kā arī raksturota viṇa izgudrotājdarbība, atklāti nopelni orientēšanās sporta popularizēšanā un sasniegumi dažāda mēroga sacensībās, tostarp viṇa izveidotajās masu sacensībās «Magnēts», kas notiek kopš 1969. gada. Šis ir pirmais pētījums par inženiera A. Līča darbību un dzīvi, kas tapis, sagaidot viṇa 80. dzimšanas dienu 2019. gada jūlijā. Tajā izmantots A. Līča personīgais arhīvs, Latvijas Valsts vēstures arhīva dokumenti un Latvijas Nacionālās bibliotēkas krājums.
\end{abstract}

Atslēgas vārdi: Arno Līcis, RPI absolventi, orientēšanās sports, «Magnēts».

\section{A. Līča ieguldījums orientēšanās sporta tautas sacensībās «Magnēts»}

RPI absolventu skaits mērāms daudzos tūkstošos, un katrs no tiem ir ko paveicis un aiz sevis atstājis nākamībai. RPI Mehānikas fakultātes absolvents Arno Līcis ir viens no tiem, kura vārds ir nesaraujami saistīts ar RPI un Latvijas Republikas dzīvi un notikumiem 20. un 21. gadsimtā. Raksta autores pievērsušās tām RPI absolventa A. Līča dzīves jomām, kurās viṇa devums ir bijis ievērojams un paliks arī nākamībai.

\footnotetext{
* Korespondējošais autors.

E-pasts: erikalanka@inbox.lv
} 
A. Līcis ir Latvijā pazīstams orientierists, un viṇam ir nozīmīga loma orientēšanās sporta tautas sacensību «Magnēts» izveidē un organizēšanā. 2019. gadā «Magnēts» atzīmē 50 gadu jubileju. Jau studiju laikā 1963. gadā A. Līcis sāka darboties Latvijas orientēšanās (sākumā tūristu) federācijas valdē. Tajā viṇa vārdu atrodam līdz pat 1973. gadam. No 1963. līdz 1983. gadam A. Līcis vadīja arī sporta biedrības «Daugava» orientēšanās sporta sekciju.

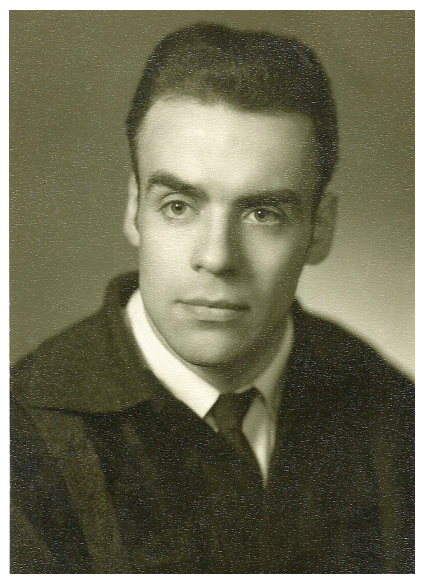

1. attēls. A. Līcis (20. gadsimta 60. gadu sākums) [1].

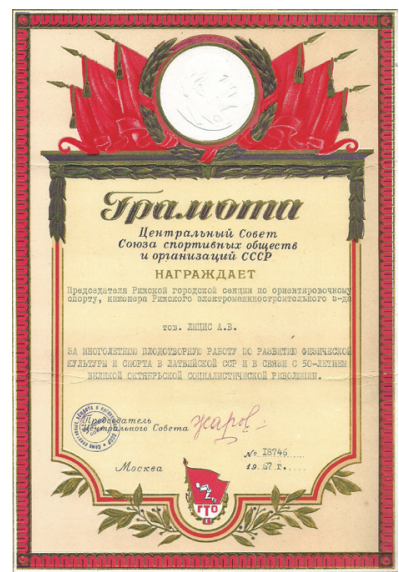

2. attēls. Padomju Sociālistisko Republiku Savienību (PSRS) Sporta biedrību un organizāciju savienības Centrālās Padomes Goda raksts A. Līcim (1967) [2].

Sporta klases Latvijas orientēšanās sportā sāka pieškirt 1966. gadā. Par PSRS sporta meistaru orientēšanās sportā A. Līcis kḷuva 1967. gadā, bet viṇa nākamā sieva Ieviṇa Līce - gadu vēlāk, 1968. gadā.

1968. gada rudenī A. Līcis izbrauca uz Zviedriju vērot orientēšanās pasaules čempionāta norisi PSRS tūristu grupas sastāvā. No Latvijas grupā bija četri cilvēki. PSRS vēl nebija starptautiskās federācijas locekle, tāpēc grupa pie oficiāliem startiem netika, bet pasaules čempionāta distancēs startēja.

Latvijas Orientēšanās federācija uzdeva A. Līcim izveidot sacensību formu darbaḷaudīm un arī sportistiem darba dienu vakaros, kas būtu piemērota dažādām vecuma un meistarības grupām. Apkopojot visu pieejamo, kas pasaulē jau bija radīts, kā arī iepazinies ar Zviedrijas orientieristu masveidību, A. Līcis ierosināja un noorganizēja orientēšanās sacensības «Magnēts-69» [3], kas bija paredzētas 10 trešdienu vakaros no plkst. 16.00 līdz 19.00. Dalībnieki varēja izvēlēties savai meistarībai un vecumam atbilstošu distanci. 1969. gada rudenī Latvijas Orientēšanās federācijas pirmais prezidents, RPI absolvents Rodrigo Slaviņš sapulcināja pārstāvjus no visiem Latvijas tūristu klubiem, un A. Līcis tos iepazīstināja ar pirmajā «Magnēta» gadā paveikto un deva ierosinājumus, kā vajadzētu uzlabot šādu sacensību norisi. Pirms «Magnēta» 
vidēji sacensībās piedalījās ap simts vīriešu un ap simts sieviešu, vēlāk ar «Magnētu» - tās pirmoreiz kḷuva par masveida Latvijas orientēšanās sacensībām.

Turpmākajos gados apmēram 20 centros notika līdzīgas sacensības. 1980. gadā Rīgas «Magnētā» vienā no trešdienām dalībnieku skaits sasniedza pat 2400. Vienā kārtā 1987. gadā bija pat 2484 dalībnieki [4]. Uz Latviju atbrauca Starptautiskās orientēšanās federācijas pārstāvji, lai iepazītos ar sasniegumiem, un viṇi izteica atzinību, ka nekur pasaulē tāda masveidība darba dienas vakaros kā Latvijas orientēšanās sacensībās nav redzēta. Arī pasaules vadošie sportisti no Skandināvijas bija vairākkārt atbraukuši un sajūsminājušies par Latvijas orientieristu sasniegumiem.

\section{A. Līča bērnība un jaunība}

A. Līcis dzimis Liepājā 1939. gada 16. jūlijā. Mātei - Frīdai Lizetei Līcei (dzimusi Karlsone, 1910-1997) [5] - no pirmās laulības bija meita Valda Bredaus (1929-2015), kura bija desmit gadu vecāka par Arno. Giimenes galva - tēvs Voldemārs Gustavs Līcis (1898-1985) - bija atslēdznieks, lokomotīves vadītājs, bet brīvajā laikā sportoja. 1930. gadā viṇš uzstādīja rekordu sporta biedrības «Marss» trekā aizmotora braucienā 15 km (15 minūtes un 5,9 sekundes), kas saglabājās nepārspēts PSRS līdz 1975. gadam. Treka riteṇbraucējs V. G. Līcis piedalījās sacensībās 20. gadsimta 30. gados [6] un vēlējās apmeklēt vasaras olimpiskās spēles 1936. gadā Berlīnē, taču tam viṇam nebija naudas.

Arno bērnības pirmie gadi pagāja Jaunliepājā. Divu gadu vecumā viṇš saslima ar astmu smagā formā un ar mainīgām sekmēm cīnījās ar
Rīgas Politehniskā

institūta

absolvents

inženieris,

izgudrotājs un

sportists

Arno Lìcis
3. attēls. 2. rindā no kreisās: A. Līča vecāki - Frīda Lizete un Voldemārs Gustavs Lī̌i (20. gadsimta 30. gadu beigas) [7].

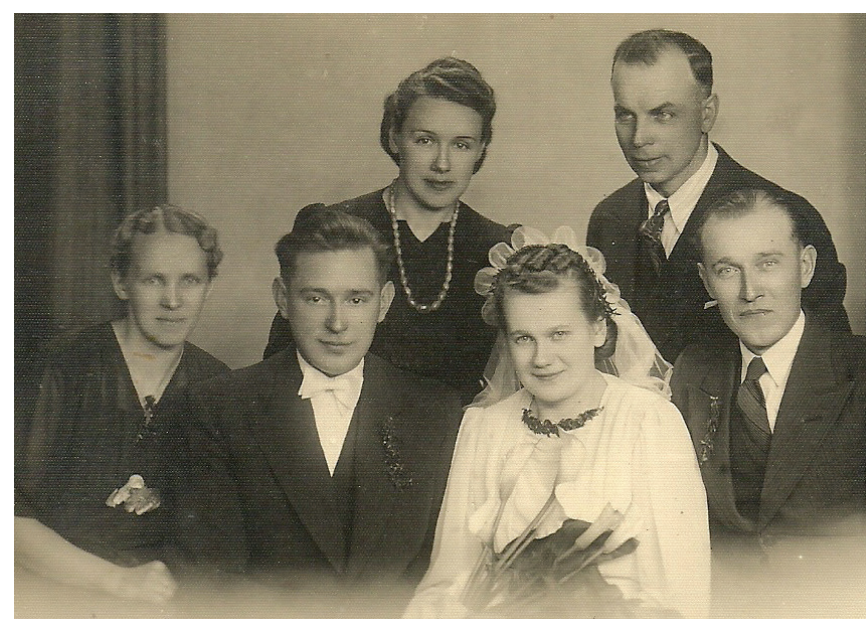


šo slimību līdz pat 1954. gadam. Slimības dēl 3. klasē nācās mācīties divreiz. Zāḷu nebija, tika izmantotas tautas medicīnas gudrības. 1944. gadā Arno izslimoja arī difterītu. Ārsti ieteica mainīt dzīvesvietu, un tā Arno nonāca Liepājas rajona Pērkones pagasta «Paisās», kur gimene dzīvoja arī Otra pasaules kara laikā. A. Līcis atceras, ka viṇš, māsa un māte pie saimnieka strādājuši visus lauku darbus, bet «visspilgtāk par šo periodu «Paisās» palicis iespaids no rudens labības apkūlībām, kad tvaika lokomotīve ar kuḷmašīnu ceḷoja no mājas uz māju un mūsu mājas labību kūla divas dienas, un talcinieki tika cienāti bagātīgi: saimnieks kāva cūku, aitu, vistas, brūvēja alu, un pēc vakara mielasta visi talcinieki - ap 20 cilvēku - dziedāja un dancoja» [8].

Pēc kara giimene pārcēlās dzīvot pie radinieces, un Arno sāka mācības Cenkones četrgadīgās skolas 1. klasē. Kad atkal bija jāmaina dzīvesvieta, viṇš mācījās Skatres septinggadīgajā skolā, kur 5.-7. klasē fizkultūras stundās iepazinās ar sporta aktivitātēm, un «saslima» ar futbolu. Tēvs uzdāvināja Arno futbola bumbu, un kopā ar skolasbiedriem viṇš spēlēja 2-3 stundas îstā izmēra futbola laukumā, līdz skolas direktors skolniekus neizdzenāja pa mājām.

Mājās Arno bija jāveic dažādi pienākumi, jāpalīdz ǵimenei apkopt mājlopus un jāstrādā piemājas dārzā. Pateicoties fiziskajām aktivitātēm, tika uzvarēta astma. Uz skolu viņš bieži brauca ar divriteni, bet ziemā ar slēpēm, jo attālums līdz skolai bija trīs kilometri [8].

\section{A. Līča mācības Rīgas Industriālajā politehnikumā}

A. Līcis izlēma turpināt mācības Rīgas Industriālajā politehnikumā (tagad - Rīgas Valsts tehnikums) un pietiecās mācībām un kārtoja septiñus iestājeksāmenus Mehānikas fakultātē. Togad uzṇēma četras grupas; viṇa grupā bija 32 zēni. Pamatskolu Arno beidza kā teicamnieks, īpaši viñam patika matemātika, geogrāfija, tomēr tehnikuma 1. kursā vinšs, pēc paša vārdiem, knapi noturējās, jo pirmajā sesijā vairākos mācību priekšmetos izḳepurojās tikai ar trijniekiem.

Rīgas Industriālā politehnikuma audzēkṇu vidū veidojās veselīga un sportiska atmosfēra. A. Līcis jau 1. kursā uzvarēja tehnikuma rudens krosā. Viņu ievēlēja par grupas fiziskās kultūras darba organizatoru. Grupa nolēma piedalīties visos sporta veidos un visās disciplīnās, un visus četrus gadus uzvarēja tehnikuma spartakiādēs [8].

A. Līcis pamazām iedzīvojās politehnikumā un pierada pie dzīves Rīgā. Jau 4. kursā vinsš bija tuvu teicamnieka godam. 1958. gadā, beidzot tehnikumu, viña grupai tika piešksirta mēnesi ilga atpūtas nometne pie Zvārtas ieža. Nometnē piedalījās arī pieci jaunieši no Igaunijas un pieci no Lietuvas. 
Mācoties politehnikumā, A. Līcis bez vieglatlētikas nodarbojās arī ar bumbu spēlēm, un pēdējā kursā pat piedalījās tehnikuma izlases treniṇos vieglatlētikā, volejbolā, basketbolā, kā arī dejoja fabrikas «Rīgas audums» tautas deju kolektīvā. 1958. gadā A. Līcis absolvēja Rīgas Industriālo politehnikumu, iegūstot tehniksa mehāniksa arodu (darba mašīnu ekspluatācija un remonts) [8].

\section{A. Līča studijas Rīgas Politehniskajā institūtā}

A. Līcis sāka strādāt Valsts elektrotehniskās fabrikas (VEF) 14. cehā, kas atradās Ganību dambī un ražoja pārvietojamās telefonu centrāles armijas vajadzībām. Sākumā viṇš strādāja par atslēdznieku pie aparātu izgatavošanas, pēc gada pārgāja uz jaunizveidoto atslēdznieku grupu, kas remontēja rūpnīcas «Komutators» metālapstrādes darba mašinnas. A. Līcis kḷuva par VEF čempionu volejbolā un futbolā. Pēc kādas spēles rokasbumbā vinš traumēja muguru, un iesaukums padomju armijā tika atlikts uz gadu. Tad arī dzima doma, ka viṇš varētu turpināt studijas augstskolā.

A. Līcis no VEF aizgāja un 1960. gada 13. maijā sāka strādāt par laborantu RPI Mehānikas fakultātes Materiālu pretestības laboratorijā [9]. Toreizējais RPI direktors Kristaps Neilands (1899-1960) izsauca Arno pie sevis, lai iepazītos. Direktors stāstīja par sevi un jautāja: «Kādi hobiji? Dzer? Pīpē?» A. Līcis atbildēja: «Sports! Bet, kad kompānija - galīgs atturībnieks neesmu» [8].

A. Līcis iestājās RPI Mehānikas fakultātes vakara nodalāa un paralēli strādāja par laborantu, izgatavoja dažādas laboratorijas darbiem nepieciešamās ierīces uz metāla apstrādes mašīnām, kā arī piedalījās laboratorijas darbu sagatavošanā RPI dienas un vakara nodaļu studentiem. Laboratorija atradās L̦eṇina (tagad - Kaḷ, kú) ielā 1, pagrabā. Kā RPI darbinieks A. Līcis piedalījās volejbola treniṇos un dažkārt spēlēja kopā ar Mehānikas fakultātes dekānu docentu Varaidotu Zaru. Kad dienas nodaḷā atbrīvojās studiju vieta, docents V. Zars semestra vidū palīdzēja Arno pāriet no vakara uz dienas plūsmu; bet šeit bija tikai studijas - bez prakses rūpnīcā. Pirmo eksāmenu sesiju, ko viṇš kārtoja vēlāk, jo bija iekavētas daudzas ieskaites un laboratorijas darbi, tomēr izdevās nokārtot apmierinoši. 1961. gada pavasarī A. Līci ievēlēja par atbildīgo par sporta aktivitātēm Mehānikas fakultātē [10]. Obligātajās fizkultūras nodarbībās viṇš apmeklēja vieglatlētiku pie Kārḷa Liepiṇa (1913-?), bet jau 1961. gada 26. martā piedalījās RPI un LVU1 draudzības sacensībās orientēšanās sportā Langstiṇos, 80 vīru konkurencē izcīnot 12. vietu. Neticamais rezultāts pirmajai reizei un - āksis lūpā. Arno

\footnotetext{
${ }^{1}$ Latvijas Valsts universitāte
} 
iestājās RPI orientieristu pulciṇā, ko vadīja Juris Jansons no Celtniecības fakultātes [11].

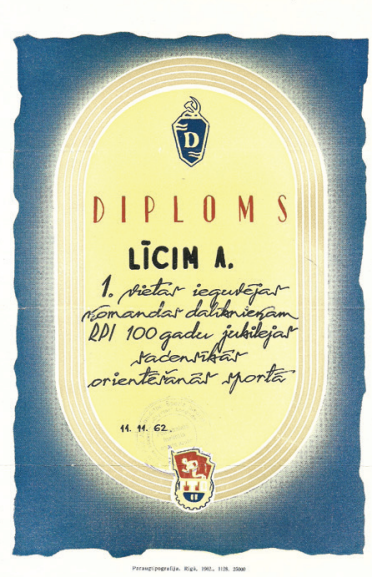

4. attēls. A. Ličca diploms par 1. vietu orientēšanās komandā RPI 100 gadu jubilejas sacensībās orientēšanās sportā. 1962. gada 11. novembrī [12].

Gaisotne orientieristu vidē bija l̦oti draudzīga. Intensīvi tika apmeklēti koptreniṇi un mēǵināts piedalīties visās iespējamās sacensībās, kurās ir orientēšanās disciplīna. Arno piedzīvoja RPI 100 gadu jubileju - 1962. gada 11. novembrī piedalījās tai veltītajās sacensībās [13]. RPI orientieristi kḷuva pazīstami Latvijā daudzu gadu garumā, izcīnot godalgotas vietas arī Latvijas izlases sastāvā. A. Līcis studiju laikā 1. Vissavienības sacensībās Užgorodā ieguva sudraba medaḷu [14]. Ar orientēšanos toreiz aktīvi nodarbojās arī Arno studiju

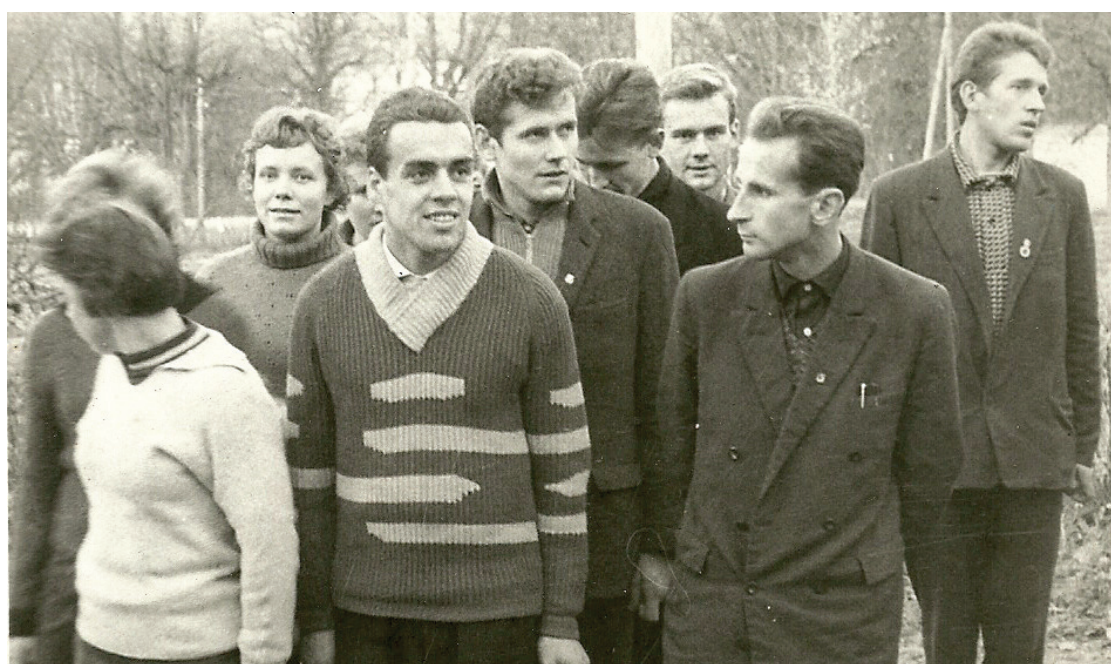

5. attēls. RPI izlase orientēšanās sportā (1962). A. Līcis - 1. rindā vidū [15]. 
biedri Helmuts Guḷevskis, Rodrigo Slavin̦š, Imants Pelns, Māris Bḷodons, Aivars Teikmanis un citi.

Izlases komandās varēja piedalīties tikai sekmīgie studenti, viṇu vidū - A. Līcis. RPI Mehānikas fakultāti viṇš absolvēja 1964. gada 26. decembrī, iegūstot inženiera mehāniksa kvalifikāciju specialitātē «Metināšanas procesu tehnoloǵijas un iekārtas» [16].

Tolaik dienas nodaḷas absolventiem bija obligāta Vissavienības jauno speciālistu sadale. Sadalē nākamās darba vietas pirmie varēja izvēlēties sekmēs labākie. Arno sekmju ziṇā bija otrais, un viṇš izvēlējās darbu Rīgas elektromašīnbūves rūpnīcā (RER), kur jau strādāja piecus mēnešus pirmsdiploma praksē.

\section{A. Līča darba gaitas Rīgas elektromašīnbūves rūpnīcā}

Izvēloties darbu RER, A. Līcis cerēja apgūt un izmantot metināšanas procesa jaunās iespējas. 1968. gadā viṇu paaugstināja par vecāko inženieri. Rūpnīcā tobrīd strādāja ap 8000 darbinieku. A. Līcis izgudrojumus un citus darbus veica kopā ar dažādu tautību cilvēkiem, kuri strādāja l̦oti godprātīgi. Liels bija arī metinātāju skaits [17]. Rūpnīcas vadība norīkoja viṇu arī par lektoru elektrokontaktmetinātāju kvalifikācijas paaugstināšanai.

Rūpnīcā daudzi procesi bija automatizēti, taču ne vienmēr darbojās tā, kā bija iecerēts. Un A. Līcim dzima jauna doma par speciālas iekārtas izveidi, kas uzlabotu ražošanas procesu. Kopā ar kolēgiem metināšanās laboratorijā vispirms tika izgatavots prototips, un kopējiem spēkiem darbs izdevās [18]. 1970. gadā RER darbojās A. Līča un kolēǵu izgudrotā «augšējās rotējošās diskveida elektrodu punktveida kontaktu metināšanas mašīna».

6. attēls. A. Lī̌ca izgudrojuma rasējums [18].

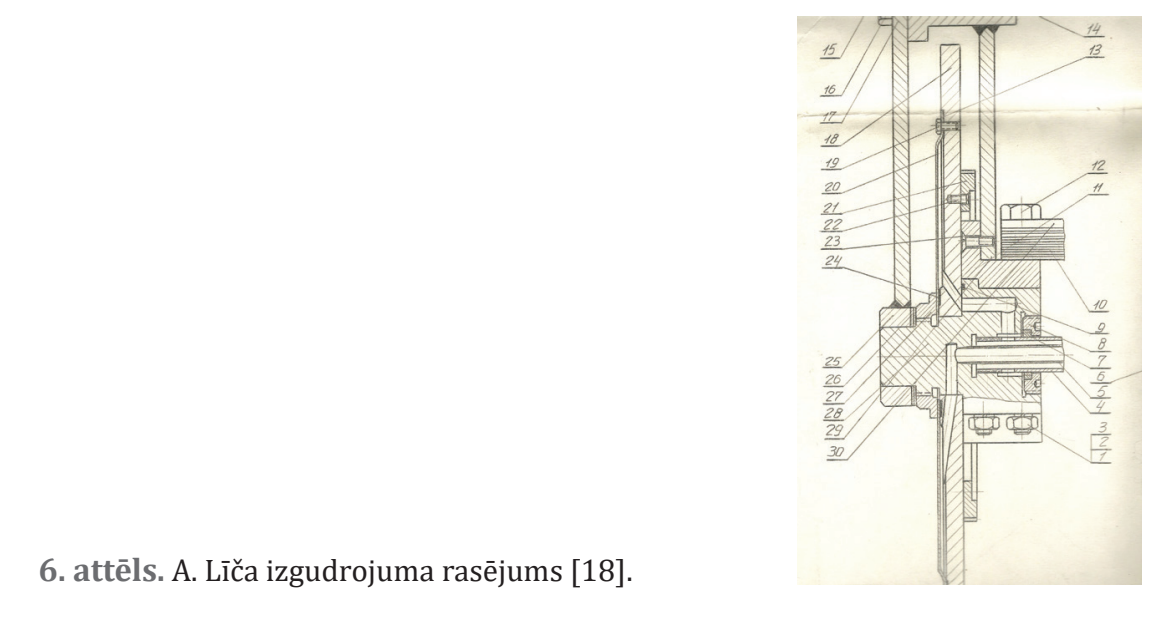

Rīgas Politehniskā

institūta

absolvents,

inženieris,

izgudrotājs un

sportists

Arno Līcis

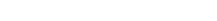


Autorapliecību A. Līcim dažādu iemeslu dēḷ noformēt neizdevās. Karjeras izaugsme bez iestāšanās Padomju Savienības Komunistiskās partijas (PSKP) rindās viṇam nebija iespējama, taču A. Līcis kompromisiem nepiekrita, partijā nestājās un savus izgudrojumus citiem neatdeva.

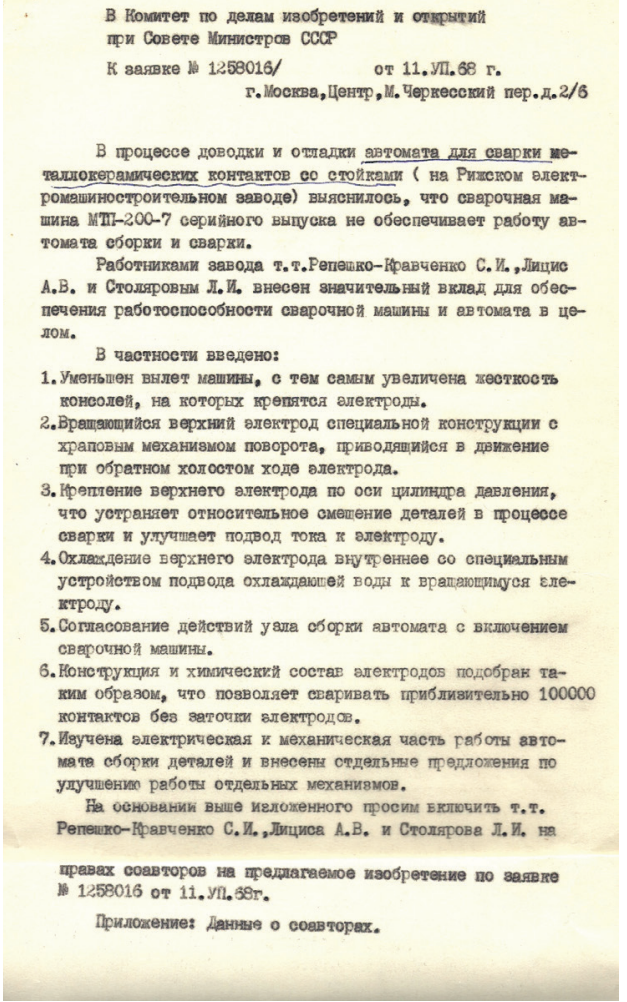

7. attēls. Pieteikuma papildinājums PSRS Ministru Padomes Izgudrojumu un atklājumu komitejai (1971) [19].

Inženieris A. Līcis tika sūtīts daudzos komandējumos ar nolūku iegādāties RER atsevišķus kontaktmašīnu mezglus, piemēram, transformatorus u. c. detal̦as. Reiz atbrauca speciāla PSRS Elektrotehniskās rūpniecības ministrijas delegācija un novērtēja A. Līča un kolēǵu paveikto: jo vairākkārt bija pārsniegti kontaktu piemetināšanas rādītāji (produktivitātes, precizitātes un savienojuma izturībā). Toreiz RER apgādāja citas ministrijas un rūpnīcas ar Latvijā ražotiem kontaktoriem.

Strādājot RER par inženieri, Arno trenēja rūpnīcas vīriešu un sieviešu komandas orientēšanās sportā un slēpošanā. Rūpnīcas orientēšanās sporta sekcijas dalībnieki palīdzēja noorganizēt republikas mēroga atklātās sacensības «Solo». Pirmās notika 1972. gadā pie Usmas ezera, tajās startēja 800 dalībnieku. Arno ar nākamo sievu Ievinuu vadīja sacensības «Solo» astoṇus gadus. No RER A. Līcis aizgāja 1975. gadā. 


\section{A. Līča darbs Latvijas Traumatologijas un ortopēdijas zinātniskās pētniecības institūtā}

Nesaskatot izaugsmes iespējas RER, A. Līcis 1975. gadā krasi mainīja savu dzīvi - pārgāja darbā uz LTOZPI par medicīniskās aparatūras inženieri, kur nostrādāja 20 gadu.

1990. gadā A. Līcis palīdzēja noorganizēt Pasaules Latviešu ārstu (PLĀ) konferenci, kas notika Rīgā un kurā vin,š bija orgkomitejas atbildīgais par sporta aktivitātēm sešos sporta veidos. Galvenie PLĀ konferences organizatori un idejas autori bija profesori Viktors Kalnbērzs (LTOZPI direktors) un Kristaps Keggi (ASV) - abi pasaulslaveni traumatologi ortopēdi.

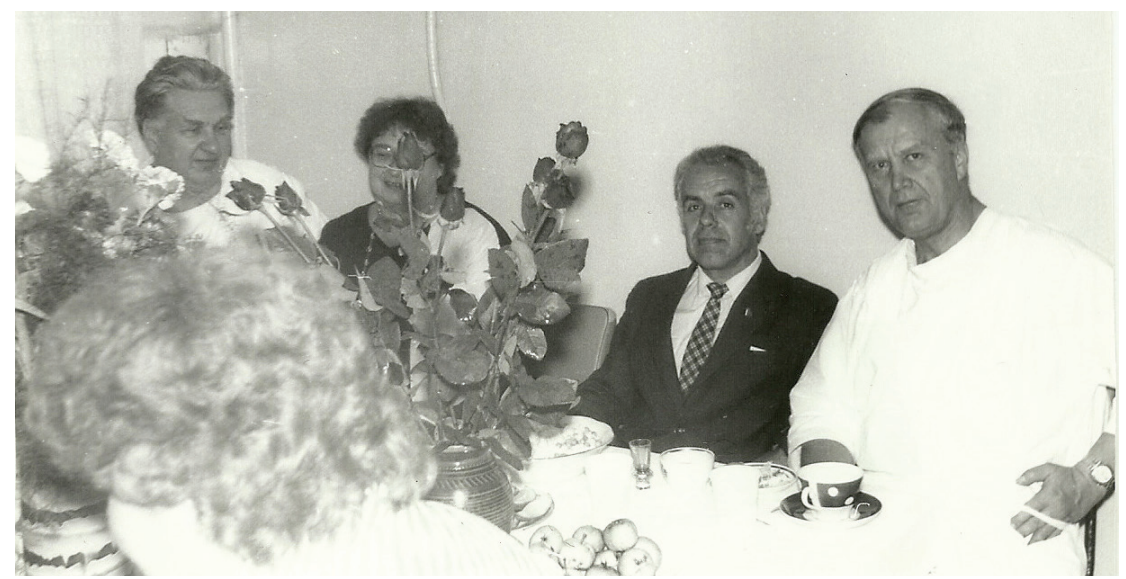

8. attēls. A. Līča (otrais no labās) 50 gadu jubilejas svinībās ar profesoru Viktoru Kalnbērzu (pirmais no labās) un LTOZPI kolēgiem (1989) [20].

LTOZPI bija vienīgā medicīnas iestāde ar savu foto-kino laboratorija, kas dokumentēja visas sarežgīitās operācijas, tāpēc visas Vissavienības un starptautiskās traumatologu konferences notika tieši Rīgā, LTOZPI klīnikas telpās. A. Līcim kā inženierim un tehniskajam darbiniekam vajadzēja aktīvi piedalīties, lai paraugoperāciju pārraides no operāciju zālēm netraucēti tiktu translētas uz Aktu zāli, kur konferenču dalībnieki varēja vērot operāciju gaitu tuvplānā, pie televizora ekrāniem.

Strādājot LTOZPI, A. Līcis iesaistījās 1987. gadā Carnikavā dibinātā pirmā orientēšanās sporta klubā «Kāpa». A. Līcis tika ievēlēts kluba valdē un piedalījās daudzos tā rīkotajos sporta pasākumos. Kluba organizētajā skrējienā «Daugava-Gauja», kas notika desmit gadus viṇš bija galvenais tiesnesis (1987-1996) [8].

Savā 20 darba gadu laikā LTOZPI aktīvu darbību mediksu sporta dzīvē A. Līcis sāka izvērst, kad viṇu institūta arodbiedrības komitejā ievēlēja 
par atbildīgo aktīvas atpūtas organizēšanā. Par LTOZPI arodbiedrības piešksirto naudu tika iegādāts vienkāršs sporta inventārs (slēpes, sporta tērpi, hokeja nūjas utt.). Institūta mediḳi spēlēja basketbolu TTT zālē, hokeja draudzības mača laikā ar «Gaiḷezera» slimnīcas ārstiem Sporta pilī vārtos stāvēja pats LTOZPI direktors profesors V. Kalnbērzs. Atbalstītāju bija pilnas tribīnes. 1990. gadā uz PSRS sportiskā tūrisma braucienā ieradās Kanādas ārstu hokeja komanda; viṇi spēlēja ar atvieglotu ietērpu, izvairoties no atklātās spēka spēles, lai nebūtu traumu. Atbraucot uz Rīgu, spēlējot ar mūsu ārstiem, kanādieši tika sirsnīgi uzn,emti: pēc hokeja spēles bija vakariṇas ar muzicēšanu un padziedāšanu. Viesi bija tādā sajūsmā, ka ielūdza Rīgas kolēgus - dakterus - nākamajā gadā apmeklēt Kanādu un piedalīties Toronto ārstu hokeja turnīrā. Šajā pasākumā 1991. gadā piedalījās arī A. Līcis (vienīgais bez ārsta kvalifikācijas), 12 dienas spēlējot hokeju 14 spēlēs dažādās pilsētās Ontario provincēs [21]. LTOZPI ārsti bija arī pie Niagāras.

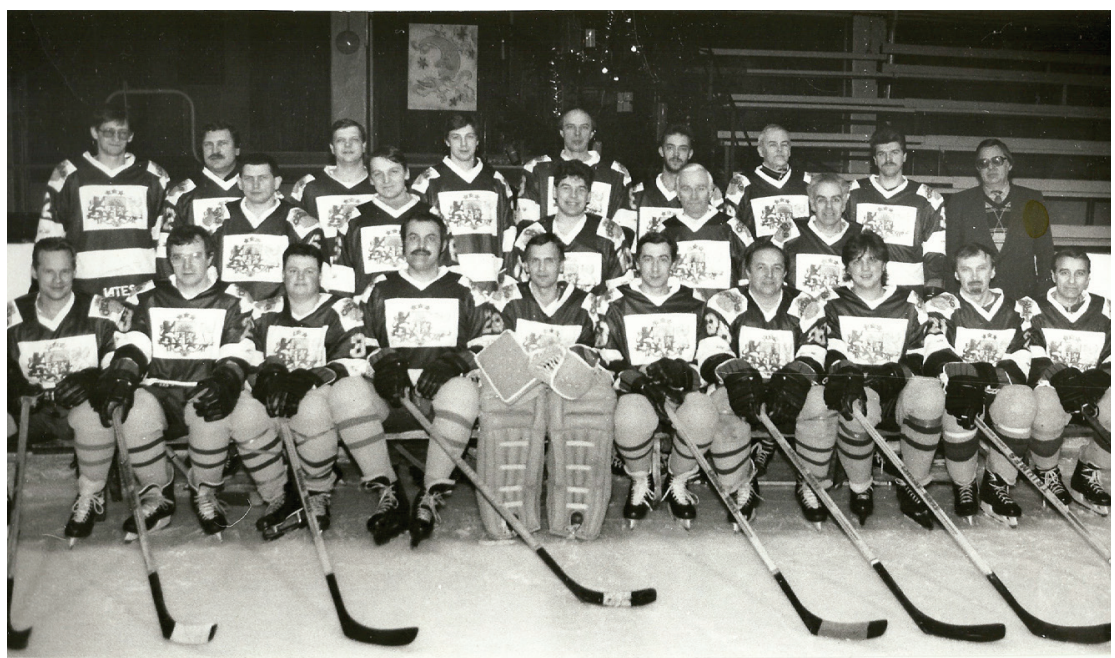

9. attēls. A. Līcis (pirmais no labās 2. rindā) LTOZPI ārstu izlases hokeja komandā Kanādā (1991) [22].

No 1985. līdz 1995. gadam apmēram 30 medicīnas darbinieku (arī nodaḷas vadītāji) piedalījās orientēšanās sacensībās «Magnēts», Tartu slēpošanas maratonā $60 \mathrm{~km}$ slēpojumā, Tartu riteņbraukšanas maratonā $120 \mathrm{~km}$ un daudzos citos garajos slēpojumos Latvijā, tādos kā Cēsis-Līgatne, Jaujas maratons u. c. Stāstot mediķiem, kas ir orientēšanās sacensības «Magnēts», A. Līcis bieži teica, ka speciāls inventārs nav vajadzīgs, izṇemot kompasu un karti, un vienīgais noteikums ir - pirmajā reizē nedrīkst skriet, bet distance jāveic soḷiem, uzmanīgi vērojot, kā kartē parādītais atbilst dabā - lai labāk saprastu orientēšanās būtību. 
Pēc 1990. gada un Latvijas neatkarības pasludināšanas LTOZPI sporta aktivitātes mazinājās. LTOZPI sāka būvēt jauno ārstniecības korpusu ar daudzām operāciju zālēm; A. Līcim iznāca braukt uz ārzemēm un tikties ar ārzemju kolēǵiem, lai mēǵinātu ierīkot labāk apgādātas operāciju zāles, ievērojot paaugstinātu sterilitāti un komfortu. LTOZPI tika reorganizēts par Valsts traumatologijas un ortopēdijas slimnīcu, un inženieri A. Līci [23] iecēla par šīs slimnīcas direktora dr. Valda Zatlera vietnieku saimnieciskos jautājumos. A. Līcis bija slimnīcas jaunā korpusa celtniecības, iekārtošanas un aparatūras iegādes un tās nodošanas ekspluatācijā tehniskais uzraugs. Šajā postenī nostrādāts pusotrs gads un tad atkal dzīvē nāca jauns pagrieziens.

1995. gada augustā tipogrāfijas «Jāṇa sēta» īpašnieki pierunāja A. Līci mainīt darbu medicīnā pret darbu poligrāfijā, uzaicinot kḷūt par tipogrāfiju «Rota-1» un «Rota-3» direktoru. Pēc ilgām pārdomām un sarunām ǵimenes lokā viṇš izšksīiās par šo pārdrošo soli - atkal ienirt nezināmā un svešā jomā. Un tūlīt pat pirmajā darba mēnesī (oktobrī) sanēma uzdevumu noorganizēt stingrās uzskaites pavadzīmju ražošanu uz papīra ar ūdenszīmju aizsardzību.

1996. gadā tipogrāfija «Rota-1» pārcēlās uz Brīvības ielu un pievienojās tipogrāfijai «Rota-3», kas drukāja un iesēja grāmatas. Dažādu iemeslu dēḷ bija jāmeklē citas telpas, un izvēle krita uz Silakrogu.

A. Līcis aizgāja pelnītā pensijā pēc devin,iem darba gadiem poligrāfijas jomā.

\section{A. Līča ǵimene, praktiskie darbi}

1968. gadā Arno satika un sāka draudzēties ar meiteni vārdā Ieviṇa, un viṇa nāca palīgā orientēšanās sacensību «Magnēts» organizēšanā. Tā viṇi 10 gadu kopā vadīja šīs sacensības: Arno - galvenais tiesnesis un Ievinga - galvenā sekretāre.

1972. gadā viṇi nodibināja ǵimeni, 1974. gadā piedzima meita Lienīte, pēc astoṇiem gadiem, 1982. gadā, - otra meita Līga, savukārt 2003. gadā - mazmeita Helēna. Paralēli visiem darbiem ar Ieviñas vecāku palīdzību tika celta māja, un pēc kāzām jaunais pāris varēja apmesties vienā tās istabā. Arno ar Ieviṇu intensīvi trenējās, jo bija Latvijas izlases dalībnieki orientēšanās sportā. Bez tam Ieviṇa un Arno Līči ir bijuši vedēji septināās kāzās.

A. Līča dzīvesbiedrei Ievin,ai 1995. gadā inficētas ērces koduma dēl attīstījās Laima slimība. Arno bija ar viṇu kopā visus garos slimības 12 gadus un 1999. gadā kopā ar draugu grupu pat uzveda viṇu Monblāna virsotnē. 


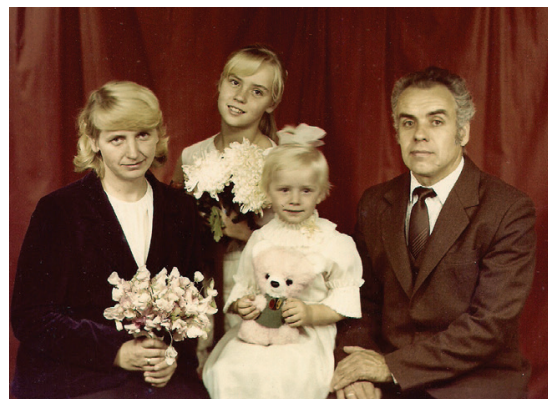

10. attēls. A. Līcis ar sievu Ievinu un meitām (20. gadsimta 80. gadi) [24].

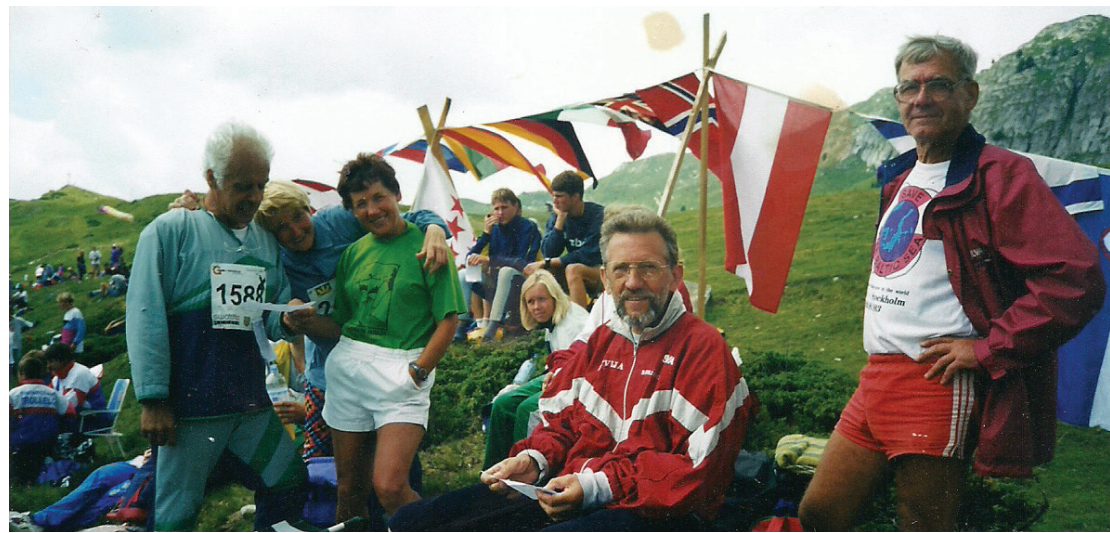

11. attēls. Arno un Ieviṇa Līči (pirmie no kreisās), otrais no labās - R. Slaviṇš, pirmais no labās - H. Guḷevskis (1937-2019) atpūtas brīdī orientēšanās sacensībās Šveicē (1999) [25].

Vēlāk - jau pēc Ieviṇas aiziešanas mūžībā 2007. gadā - viṇš pieṇēma pie sevis un kopa savu māsu Valdu līdz viṇas mūža beigām 2015. gadā. Tas nebija viegli, bet tas bija jādara.

A. Līča pelnītās atpūtas laiks nu ir piepildīts tikpat blīvi kā darba gados: sporta veterānu mači, dārza darbi, mājas labiekārtošana, grāmatu lasīšana, biškopība, dārzkopība (siltumnīcā aug viss, kas galdam vajadzīgs), auglkopība.

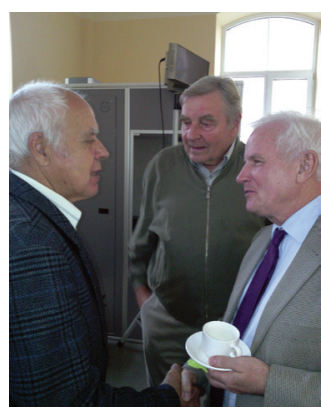

12. attēls. No kreisās: A. Līcis ar savu RPI mācībspēku Aini Kārkliṇu un RTU administratīvo direktoru Janu Šlihti RTU Vēstures dienā 2018. gada 10. oktobrī [26]. 


\section{Nobeigums}

RPI studenti un absolventi, kuri strādājuši Latvijai un veikuši nenovērtējamu un paliekošu darbu, ir skaitāmi ne jau desmitos vien. Vinu vidū ierindojams arī Arno Līcis - RPI absolvents, inženieris, izgudrotājs, orientēšanās sportists, sporta dzīves organizators, masu sacensību «Magnēts» radītājs, tēvs, vīrs, dārznieks, bitenieks, vedējtēvs, «Latvijas Lepnuma» nominants. Piedzimis vēl neatkarīgās Latvijas valsts laikā, viṇš vienmēr pauda skaidru nostāju un atklāti izteica pārliecību. Tikmēr vina intelektuālās, organizatoriskās un saskarsmes spējas un kompetences bija tik izcilas, ka arī padomju laikā kolēǵi, vadītāji un ierēdṇi tās augstu novērtēja un piedāvāja izmēgināt netipiskas lietas viṇa karjerā [8]. Viṇa profesionālā darbība un sporta sasniegumi, cilvēciskās kvalitātes un optimisms radīja nepārvērtējamu ieguldījumu Latvijai viṇa radītais «Magnēts» 2019. gadā notika jau 51. reizi.

2006. gadā par pašaizliedzību un panākumiem, strādājot Latvijas valsts un tautas labā, A. Lìcis apbalvots ar LR Ministru kabineta Atzin̄̄bas rakstu [27]. Rīgas Tehniskā universitāte, RPI tradīciju un darba pārmantotāja, var lepoties ar tādiem absolventiem.

\section{INTEREŠU KONFLIKTS}

Zinātniskā raksta autores atzīst interešu konfliktu, kas saistīts ar autoru un redkolēǵijas kopēju profesionālo darbību. Par šī raksta iekḷaušanu krājumā lēmumu pieṇēma tie redkolēǵijas locekḷi, kas nav raksta autori.

\section{AVOTU UN LITERATŪRAS SARAKSTS}

[1] A. Līcis (20. gadsimta 60. gadu sākums). Foto no A. Lī̌ca personīgā fotoarhīva. 11. apr., 18994 l., 4. lp.

[2] PSRS Sporta biedrību un organizāciju savienības Centrālās Padomes Goda raksts A. Līcim. (1967). No A. Līča personīgā arhīva.

[3] Paikena, V. «Magnēta» bums. Liesma, 1983. gada 1. septembris, Nr. 9, 6. lpp.

[4] Jaunzemis, J. Magnēts bija un būs. Diena, 1993. gada 6. decembris, Nr. 263, 7. lpp.

[5] Frīdas Lizetes Līces Latvijas Republikas pavalstnieces pase. 20. gadsimta 30. gadi. Latvijas Latvijas Nacionāla arhīva Latvijas Valsts vēstures arhīvs (turpmāk - LNA LVVA) 2996. f., 11 apr., 18994 l., 4. lp.

[6] Latvijas meistarsacīkstes riteņbraukšanā. Stadions, 1933. gada 14. augusts, Nr. 48, 5. lpp. 
[7] Arno Līča vecāki - Frīda Lizete un Voldemārs Gustavs Līči. (20. gadsimta 30. gadu beigas). Foto no A. Līča personīgā fotoarhīva.

[8] Ėrikas Lankas intervija ar Arno Līci 2018. gada 27. septembrī. Ė. Lankas personīgais arhīvs.

[9] Laboranta Arno Līča personāllieta. RTU arhīvs.

[10] Arno Līča studenta personāllieta. RTU arhīvs.

[11] Jansons, J. Mūsu tūristi - Vissavienības sacensību uzvarētāji. Jaunais Inženieris, 1962. gada 20. februāris, Nr. 3, 4. lpp.

[12] Diploms A. Līcim par 1. vietu orientēšanās komandā RPI 100 gadu jubilejas sacensībās orientēšanās sportā. 1962. gada 11. novembrī. No Arno Līča personīgā arhīva.

[13] Tuvojas LVU orientēšanās sacensības. Padomju Students, 1962. gada 16. novembris, Nr. 29, 2. lpp.

[14] Pelns, I. Atjautīgo un izturīgo sports. Jaunais Inženieris, 1963. gada 9. decembris, Nr. 19, 4. lpp.

[15] RPI izlase orientēšanās sportā (1962). A. Līcis - 1. rindā vidū. Foto no A. Līča personīgā fotoarhīva.

[16] Arno Līča RPI diploms. 1964.gads. No A. Lī̌ca personīgā arhīva.

[17] Ždanovs, V. Ar kompasu un karti. Rezietis, 1974. gada 3. jūnijs, 2. lpp.

[18] Arno Līča izgudrojuma rasējums. No Arno Līča personīgā arhīva.

[19] Pieteikuma papildinājums Izgudrojumu un atklājumu komitejai pie PSRS Ministru Padomes (1971). No A. Līča personīgā arhīva.

[20] Arno Liča (otrais no labās) 50 gadu jubilejas svinībās ar profesoru Viktoru Kalnbērzu (pirmais no labās) un LTOZPI kolēǵiem (1989). Foto no A. Lìča personīgā fotoarhīva.

[21] Žīgurs, A. Rīgas ārsti Kanādā. Latvija Amerikā, 1991. gada 20. aprīlis, Nr. 16, 8. lpp.

[22] A. Līcis (pirmais no labās 2. rindā) LTOZPI ārstu izlases hokeja komandā Kanādā (1991). Foto no A. Līča personīgā fotoarhīva

[23] Lībrins, A. Vai dolāri paliks Latvijā? Diena, 1991. gada 9. jūlijs, Nr. 128, 2. lpp.

[24] Arno Līcis ar sievu Ieviṇu un meitām (20. gadsimta. 80. gadi). Foto no A. Līča personīgā fotoarhīva.

[25] Arno un Ievin,a Līči (pirmie no kreisās), otrais no labās - R. Slaviṇš, pirmais no labās - H. Guḷevskis (1937-2019) atpūtas brīdī orientēšanās sacensībās Šveicē (1999). Foto no A. Līča personīgā fotoarhīva.

[26] A. Līcis ar savu RPI mācībspēku Aini Kārkliṇu un RTU administratīvo direktoru Janu Šlihti RTU Vēstures dienā 2018. gada 10. oktobrī. Foto no Ērikas Lankas personīgā fotoarhīva.

[27] Karlsons, P. Sports. Laiks, 2006, 10. jūnijs, Nr. 24, 24. lpp. 


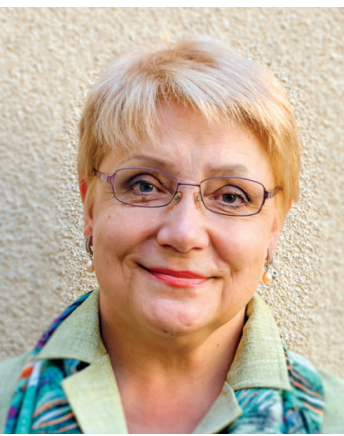

ËRIKA LANKA, $M g$. paed., $M g$. phil., graduated from

Rīgas Politehniskā University of Latvia. From 1984, she has been a lecturer with the Faculty of Education at University of Latvia, from 2008 to current time she works as Director of one of the Programmes at the Centre of Adult Pedagogical Education at the Faculty of Education, Psychology and Art. She participates as an expert in a lot of Latvian and foreign research projects, at the same time working as a teacher at schools. Her main academic interests include the philosophy of education, ethics, axiology, values and codex of teacher, history of pedagogy in Latvia and in Europe. She is a co-author of two monographies and the author of more than 30 publications.

Address: Imantas 7. linija, 1, Riga, LV-1083, Latvia

Phone: +371 29264829

E-mail: Erika.Lanka@lu.lv,erikalanka@inbox.lv

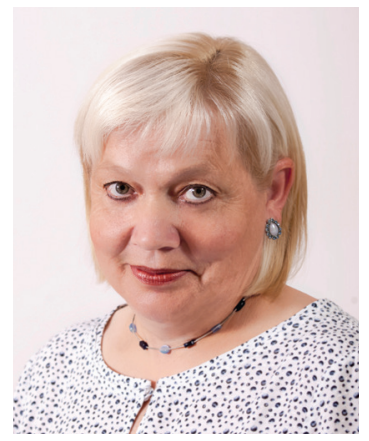

ALĪDA ZIGMUNDE, Dr. paed., has been a Specialist at the Museum of Riga Technical University since 1989. From 2007 to 2015, she was a Senior Researcher. She is currently a Professor with the Institute for Humanities and Head of the Department for Historic Research and Scientific Publications of the RTU Research Centre for Engineering History. Her main academic interests include the history of pedagogy in Europe, the history of the institutions of education and of private schools and the history of pedagogy of universities, history of engineering sciences and universities.

Address: 1 Kronvalda bulvāris, Room 203, Riga, LV-1010, Latvia

Phone: +37129869642

E-mail: alida.zigmunde@rtu.lv

Alīda Zigmunde, Ērika Lanka

\section{Graduate of Riga Polytechnic Institute, Engineer, Inventor and Athlete Arno Lïcis}

The article summarizes the career of a graduate of the Faculty of Mechanics (1964) of Riga Polytechnic Institute Arno Licis. The article reveals and describes his work while being an engineer at the Riga Electromachine Building Factory $(R E R)$, at the Latvian Scientific Research Institute of Traumatology and Orthopaedics (LSRITO) and in the printing house "Jāna sēta», as well as being an inventor. It has been discovered that he had promoted orienteering sports and had significant achievements in competitions of various scale, including mass competition named «Magnèts» managed by him, which had been taking place since 1969. This is the first research on the life and professional activities of 
engineer A. Licis, which is dedicated to his 80th birthday to be celebrated in July 2019. Data from the personal archive of A. Licis, documents of the Latvian State Archives and the collection of the National Library of Latvia are collected in this article.

Keywords: Arno Lìcis, graduates of RPI, orienteering sports, «Magnēts».

Эрика Ланка, Алида Зигмунде

\section{Выпускник Рижского политехнического института, инженер, изобретатель и спортсмен Арно Лицис}

В статье обобщен вклад выпускника Механического факультета Рижского политехнического института (РПИ) 1964 года Арно Лициса в профессию инженера на Рижском электромашиностроительном заводе (РЭЗ), в Латвийском институте травматологии и ортопедии (ЛИТО), типографии «Jāna sēta», а также охарактеризована его изобретательская деятельность, выявлены заслуги в популяризации спортивного ориентирования и достижения в различного рода соревнованиях, в том числе в организованных им массовых соревнованиях «Magnēts», которые проводятся с 1969 года. Это первое исследование деятельности и жизни инженера А. Лициса, которое проводится в преддверии его 80-летия в июле 2019 года. В нем использован личный архив А. Лициса, документы Государственного архива Латвии и собрание Латвийской Национальной библиотеки.

Ключевые слова: Арно Лицис, выпускники РПИ, спортивное ориентирование, «Magnèts». 